\title{
RECALCULATION OF FOREST INCREMENT, MORTALITY AND HARVEST RATE IN LATVIA ACCORDING TO UPDATED LAND USE DATA
}

\begin{abstract}
Linards Ludis KRUMSTEDS, Latvian State Forest Research Institute "Silava", Rigas iela 111, LV-2169 Salaspils, Latvia, linards.krumsteds@ silava.lv (corresponding author)

Andis LAZDINS, Latvian State Forest Research Institute "Silava", Rigas iela 111, LV-2169 Salaspils, Latvia, andis.lazdins@ silava.lv Aldis BUTLERS, Latvian State Forest Research Institute "Silava", Rigas iela 111, LV-2169 Salaspils, Latvia, aldis.butlers@ silava.lv Janis IVANOVS, Latvian State Forest Research Institute "Silava", Rigas iela 111, LV-2169 Salaspils, Latvia,janis.ivanovs @ silava.lv

National forest inventory (NFI) is an efficient way to monitor forest resources, including increment, mortality, and harvest rate. It provides accurate statistical information about land use data, land use change and biomass stock change and enables to tie the specific increment, mortality and harvest data to defined land use category, dominant tree species, site types etc. Recently there have been introduced changes in land use calculation method using NFI data in Latvia. New calculation method takes into account present land use data and land use data from two previous cycles considerably reducing uncertainty of the estimates and takes into account possible land management practices which may alter the land use category in long-term, also usage of auxiliary data has been introduced to increase accuracy of determination of final land-use category. Changes in land use calculation method directly affects distribution of data on increment, morality and harvests between land use categories. The aim of the study is to determine increment, mortality and harvest rate in Latvia between the first and third NFI cycle (2004-2018) using updated land use data and to compare obtained result with data from the most recent greenhouse gas (GHG) inventory report.
\end{abstract}

Keywords: Harvest rate, increment, mortality, land use and land use change, national forest inventory.

\section{INTRODUCTION}

Forests and trees on non-forest lands is significant provider of ecosystem services and economic goods. They contribute to growth of national economies by providing broad range of natural resources and contributing to ecosystem services by maintaining biodiversity and regulating water regime (Gupta et al., 2019; Verkerk et al., 2019). Accurate and reliable information about land use and land use changes, forest increment, mortality and harvest rate in the country is important data source for international agencies, governmental and non-governmental organizations which can use provided data for implementation of climate policies and action plans (Keenan et al., 2015). Also, there is considerable social pressure which demands up-to-date statistical information about natural resources which can be used for implementation of short-term and long-term management plans and policies (Heikken et al., 2012).

Due to the importance of woodlands most of the European countries have implemented National forest inventories (NFI) which provide reliable source of national forest and/or woodland related statistical information. NFI data is the result of intensive fieldwork which provides data of rapidly increasing value, because of the projects longevity and continuous longterm data flow (Gschwantner et al., 2016; Traub et al., 2017). Harmonization of NFI data is in process in Europe. European National Forest Inventory Network (ENFIN) has been established to be a platform and mediator to European countries to exchange information about the differences in methods and modules which can improve or harmonize already existing NFIs thus ensuring that estimates of forest resources are comparable over long periods of time and across large range of administrative borders throughout Europe (Vidal et al., 2016). Harmonized data helps to implement different forest-related policies more effortlessly in the European Union (EU) scale ensuring possibility to report various forest resource related statistics under various international agreements, including the EU common climate change mitigation targets (Vauhkonen et al., 2019). NFI data are gathered using statistical sampling approach, thus ensuring possibility to assess uncertainty which can result from sampling (Heikken et al., 2012). Despite the fact that NFI data provides continuous and reliable data, because of the data gathering specifics country-level yearly estimates requires interpolation or extrapolation calculation providing additional uncertainty (Heikken et al., 2012; McMahon et al., 2019).

The increment, mortality and harvest rate in woodlands are the key elements to determine changes of growing stock which is significant information for forestry projections, which indicates that harvest rate and mortality should not transcend

Copyright $\odot 2019$ The Authors. Published by Vytautas Magnus University. This is an open-access article distributed under the terms of the Creative Commons Attribution License (CC BY 4.0), which permits unrestricted use, distribution, and reproduction in any medium, provided the original author and source are credited. 
the increment in the medium term (Forest Europe, 2011). Estimation of mortality of trees helps to acknowledge information about the volume loss not caused by human activities but due to the natural causes, like windfalls, natural forest fires, decayed trees, animal related damages, etc. (Bertini et al., 2019). Also, the mortality rate is important to project stock of dead biomass in woodlands contributing to the biodiversity and regeneration of soil carbon stock (Verkerk et al., 2019).

The aim of the study is to determine increment, mortality and harvest rate in woodlands in Latvia using updated land use data and to compare acquired data with the current GHG inventory report.

\section{MATERIALS AND METHODS}

\section{Study area}

NFI plots are covered throughout entire area of Latvia. In total 16157 plots are scattered through $64589 \mathrm{~km}^{2}$ and each individual plot is visited once in 5-year period, also called cycle. Area of each individual plot is $500 \mathrm{~m}^{2}$ each representing 400ha of the country area (Formula 1 and 2). If individual plot contains more than one land use category, it is divided into smaller units called sectors. Each individual plot represents the land use category determined when the plot is inspected by field measurement teams. In case of multiple sectors in a plot size of the sectors is determined by field measurement teams when plots are visited.

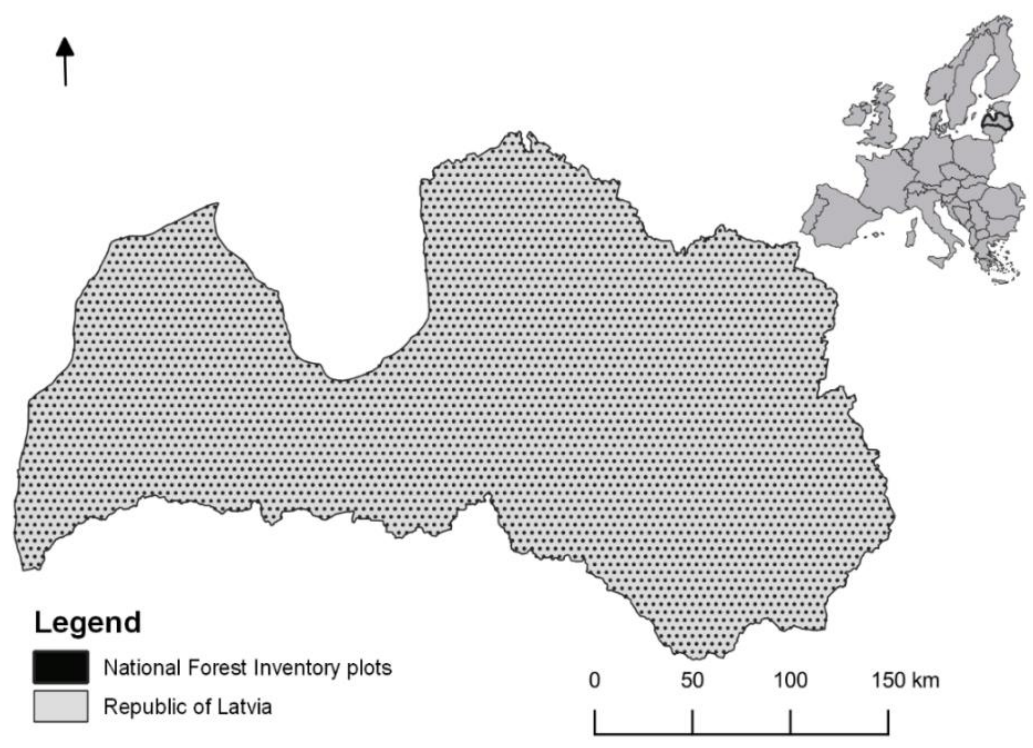

Figure 1. NFI plot coverage in Latvia

\section{Recalculated land use data and plot area data extrapolation to represent countries territory}

Information of recalculated land use data are used to determine more precise land use information for each individual plot. Recalculated data takes excludes to large extend cases when date on land use change during the fields works are determined inaccurately, because of data gathering specifics, e.g. each individual plot is visited only once per cycle resulting in potential overestimation of afforestation and deforestation of recently afforested areas due to temporal changes in management practices.

Also, alterations with auxiliary data are implemented. One of the applied auxiliary data is land parcel information system (LPIS), which is obtained from Rural Support Service. LPIS data provides information about permanent and cultivated grassland and cropland areas. If grassland in NFI plot intersects with a polygon of sown grassland in LPIS the land use category is changed to cropland. This eliminates potential errors where field measurement teams during field work have reported grassland as a land use category, but the grassland is sown and regularly cultivated and possibly will be plowed next season to change cultivated crop.

To determine territory of the country represented by each plot it is calculated as proportion between total area of all the NFI plots and the area of Latvia,

$$
\text { Unit coefficient }=\frac{\sum \text { of all plot shape area }}{\text { Country area }}
$$

and afterwards area represented by a sector or plot can be calculated using following formula,

$$
\text { Extrapolated NFI plot area in ha }=\frac{\sum \text { of all the plot shape area }}{\text { Unit coefficient }}
$$


Extrapolated plot area can be used in further extrapolation of NFI statistical data, which is combined with geospatial information of each plot, thus allowing to determine stock, increment, harvest and mortality of trees in the whole country.

\section{Extrapolation of NFI data on increment, mortality and harvest to represent information about whole country}

Wood mortality is calculated by combining statistical information on volume of trees which are damaged by animals, weather, withering or breaking or other influence and are not transported outside their original location. The gathered data afterwards are extrapolated to represent natural mortality of trees in whole country using Formula 4.

$$
\text { Mortality } \mathrm{m}^{3}=\text { plot area MORm }{ }^{3} * \text { extrapolated NFI plot area in ha }
$$

Wood harvest represents volume of trees that have been either damaged naturally or harvested and transported outside its original location. To represent situation in whole country statistical information from each plot about harvest is extrapolated as shown in Formula 5.

$$
\text { Harvest } \mathrm{m}^{3}=\text { plot area } \mathrm{HWm}^{3} * \text { extrapolated NFI plot area in ha }
$$

Extrapolated data are used to create summary tables representing stock changes, gross increment, harvest and mortality of trees in each land use category.

Increment is calculated as difference of growing stock between cycles plus mortality and harvest in the period represented by both cycles as represented in Formula 3. Following to the approach implemented in the GHG inventory these data are applied to the period represented by the most recent NFI cycle.

$$
\text { Increment } \mathrm{m}^{3}=\left(\text { growing stock } \mathrm{m}^{3} \text { cycle } 3 / \text { cycle } 2 \text { - growing stock } \mathrm{m}^{3} \text { cycle } 2 / \text { cycle } 1\right)+\text { mortality } \mathrm{m}^{3}+\text { harvest } \mathrm{m}^{3}
$$

\section{RESULTS}

\section{NFI data on gross volume increment of trees between cycles}

In forest land the volume increment of trees in the period between cycle 3 and 2 has experienced considerable increase compared to the period between cycle 2 and cycle 1 which has also resulted in raise of total wood increment during the same time period. Decrease in increment is detected in cropland, grassland, settlements and wetlands. If compared to the gross volume increment figures reported in the GHG inventory report, recalculated values in forest lands are by $3 \%$ smaller in the period represented by the cycle 2 and 1 and bigger by $9 \%$ in the period represented by the cycle 3 and 2 . This means that the impact of recalculation of land use on the increment values in forest lands is significant. For other land use categories stock change approach is used in the NFI therefore the difference cannot be calculated.

Table 1 . Gross increment of trees in $\mathrm{m}^{3}$ between cycle $2 /$ cycle 1 and cycle $3 /$ cycle 2 .

\begin{tabular}{lcccccrr}
\hline \multicolumn{7}{c}{ Difference between cycle 2/cycle 1 } \\
\hline Land use & Cropland & Forest land & Grassland & Other land & Settlements & Wetlands & Total \\
\hline Total value & 215012 & 22726580 & 939994 & 12072 & 1421396 & 530428 & 25845482 \\
\hline \multicolumn{7}{c}{ Difference between cycle 3/cycle 2 } \\
\hline Total value & 18490 & 26509335 & 54363 & 9623 & 245556 & 5929 & 26715325 \\
\hline
\end{tabular}

\section{NFI data about mortality of trees between cycles}

Mortality of trees has slightly increased in forest land and wetlands in the most recent period as it can be seen in Table 3. Mortality rates in cropland and other land use category have stayed in the same range, but mortality in grassland and settlements has fallen compared to the period represented by cycle 2 and 1. If compared to the data on mortality in forest lands reported in the GHG inventory recalculated values are by 13\% smaller in the period represented by the cycle 2 and 1 and by $1 \%$ bigger in the period represented by cycle 3 and 2 . This result is pointing on an underestimation of increase of the mortality in forest lands in the GHG inventory. Obtained results also substantiate significant impact of recalculation of land use on distribution of mortality of trees across land use categories.

Table 3 . Mortality of trees in $\mathrm{m}^{3}$ between cycle $2 /$ cycle 1 and cycle $3 /$ cycle 2 .

\begin{tabular}{lrrrrrrr}
\hline \multicolumn{7}{c}{ Difference between cycle 2/cycle 1 } & \\
\hline Land use & Cropland & Forest land & Grassland & Other land & Settlements & Wetlands & Total \\
\hline Total value & 6973 & 6019607 & 87372 & 0 & 133873 & 31453 \\
\hline \multicolumn{7}{c}{ Difference between cycle 3/cycle 2 } & 6279277 \\
\hline Total value & 6278 & 6264926 & 45808 & 0 & 55887 & 38621 & 6411520 \\
\hline
\end{tabular}


Even though mortality of trees in forest land has increase according to Table 3 in Table 4, where mortality of trees has been showed per hectare, it is shown that the average values per area has been slightly decreased. Values representing other land use categories in Table 4 are indicating the same trends as in Table 3, respectively, in cropland, grassland and settlements mortality decreased but in wetlands slight increase has been found. Even though mortality of trees is increasing according to Table 3, average mortality rates presented in Table 4 are actually indicating slight decrease, which is result of increase of area of woodlands.

Table 4. Mortality of trees in $\mathrm{m}^{3} \mathrm{ha}^{-1}$ between cycle $2 /$ cycle 1 and cycle $3 /$ cycle2.

\begin{tabular}{lrrrrrrr}
\hline Land use & Cropland & Forest land & Grassland & Other land & Settlements & Wetlands & Total \\
\hline Average value & 0,42 & 2,03 & 0,40 & 0,00 & 1,23 & 0,34 \\
\hline Average value & 0,50 & \multicolumn{7}{c}{ Difference between cycle 3/cycle 2 } & 1,85 \\
\hline
\end{tabular}

\section{NFI data about harvest of trees between NFI cycles}

Table 5 is indicating that the harvest rate has significantly increased in the period represented by the NFI cycle 3 and cycle 2 in comparison to period represented by cycle 2 and cycle 1 . Settlement, wetland, grassland and cropland have experienced less harvests in the period represented by cycle 3 and cycle 2 in comparison to the period represented by cycle 2 and cycle 1, which proves that main harvest activities in Latvia are conducted on forest lands and harvests in other land use categories, including deforestation are minor. Compared with the total harvest data reported in the GHG inventory recalculated values are by $6 \%$ bigger in the period represented by the cycles 2 and 1, and by $2 \%$ bigger in the period represented by the cycles 3 and 2. In spite the difference is not significant it points to significant conclusion that recalculation of spatial data, particularly correction of area of sectors have impact on total reported values, e.g. harvest rate.

Table 5. Total harvest rate in $\mathrm{m}^{3}$ between cycle $2 /$ cycle 1 and cycle $3 /$ cycle 2 .

\begin{tabular}{lrrrrrrr}
\hline \multicolumn{7}{c}{ Difference between cycle 2/cycle 1 } \\
\hline Land use & Cropland & Forest land & Grassland & Other land & Settlements & Wetlands \\
\hline Total value & 54436 & 14812074 & 301248 & 156 & 710710 & 61698 & 15940322 \\
\hline & & \multicolumn{7}{c}{ Difference between cycle 3/cycle 2 } & & \\
\hline Total value & 47193 & 16845407 & 162002 & 0 & 588487 & 41677 & 17684766 \\
\hline
\end{tabular}

\section{CONCLUSION}

- Recalculation of land use has significant impact on distribution of gross increment, mortality and harvests between land use categories, as well as total values, therefore these figures should be updated in the GHG inventory in the recalculated land use data are used.

- Recalculation proves that gross volume increment of trees in Latvia has considerably increased recently which has also been indicated as increment of growing stock.

- Harvests in forest land has also increased in Latvia in the period represented by the NFI cycle 3 and 2, which has led to increase of total harvest rate in Latvia. In cropland, grassland, settlements and wetlands harvest during this period has decreased, proving decrease of deforestation of newly afforested areas. Redistribution of harvests is also associated with recalculation of land use data.

- Recalculation also proved that mortality of trees has increased in forest lands in the recent years as a result of aging of forests, which is clearly defined by the NFI data.

- Further spatial processing of the gross increment, mortality and harvest data is necessary to estimate impact of land use change on these values and uncertainty of the estimates.

\section{REFERENCES}

1. Bertini G., Ferretti F., Fabbio G., Raddi S., Magnani F. 2019. Quantifying tree and volume mortality in Italian forests. Forest Ecology and Management, Vol. 444, pp.42-49. https://doi.org/10.1016/j.foreco.2019.04.006

2. Forest Europe, 2011. State of Europe's Forests 2011. Status and Trends in Sustainable Forest Management in Europe. Ministerial Conference on the Protection of Forests in Europe, Oslo.

3. Gschwantner T., Lanz A., Vidal C., Bosela M., Di Cosmo L., Fridman J., Gasparini P., Kuliešis A., Tomter S., Schadauer K. 2016. Comparison of methods used in European National Forest Inventories for the estimation of volume increment: towards harmonisation. Annals of Forest Science, Springer Verlag/EDP Sciences, Vol. 73 (4), pp.807-821. https://doi.org/10.1007/s13595-016-0554-5

4. Gupta R., Sharma L. K. 2019. The process-based forest growth model 3-PG for use in forest management: A review. Ecological Modelling, Vol. 397, pp.55-73. https://doi.org/10.1016/j.ecolmodel.2019.01.007 
5. Heikkinen J., Tomppo E., Freudenschuss,A., Weiss P., Hylen G., Kušar G., Ståhl G.,2012. Interpolating and Extrapolating Information from Periodic Forest Surveys for Annual Greenhouse Gas Reporting. Forest Science, Vol. 58(3), pp. $236-247$. https://doi.org/10.5849/forsci.10-086

6. Keenan R. J., Reams G. A., Achard F., de Freitas J. V., Grainger A., Lindquist E. 2015. Dynamics of global forest area: Results from the FAO Global Forest Resources Assessment 2015. Forest Ecology and Management, Vol. 352, pp. 9-20. https://doi.org/10.1016/j.foreco.2015.06.014

7. McMahon S. M., Arellano G., Davies S. J. 2019. The importance and challenges of detecting changes in forest mortality rates. Ecosphere, Vol. 10(2). Pp. 1-10, https://doi.org/10.1002/ecs2.2615

8. Traub B., Meile R., Speich S., Rösler E. 2017. The data storage and analysis system of the Swiss National Forest Inventory. Computers and Electronics in Agriculture, Val. 132, pp. 97-107. https://doi.org/10.1016/j.compag.2016.11.016

9. Vauhkonen J., Berger A., Gschwantner T., Schadauer K., et al. 2019. Harmonised projections of future forest resources in Europe. Harmonised projections of future forest resources in Europe. Annals of Forest Science, Vol. 76, ID 79. https://doi.org/10.1007/s13595$\underline{019-0872-5}$

10. Verkerk P. J., Fitzgerald J. B., Datta P., Dees M., Hengeveld G. M., Lindner M., Zudin S. 2019. Spatial distribution of the potential forest biomass availability in Europe. Forest Ecosystems, Vol. 6(1). https://doi.org/10.1186/s40663-019-0163-5

11. Vidal C., Alberdi I., Redmond J., Vestman M., Lanz A., Schadauer K. 2016. The role of European National Forest Inventories for international forestry reporting. Annals of Forest Science, Springer Verlag/EDP Sciences, Vol. 73 (4), pp.793-806. https://doi.org/10.1007/s13595-016-0545-6 